\title{
IMPLEMENTASI PERLINDUNGAN HUKUM TERDAHAP HAK \\ MATERNITAS PEKERJA WANITA DI KAWASAN BERIKAT \\ NUSANTARA (KBN) CAKUNG JAKARTA UTARA DITINJAU DARI UNDANG-UNDANG KETENAGAKERJAAN \\ (STUDI KASUS PELANGGARAN HAK MATERNITAS PEKERJA WANITA DI WILAYAH KBN CAKUNG, JAKARTA UTARA)
}

\author{
Melisa Kurniawan Ardianto \\ (Mahasiswi Program S1 Fakultas Hukum Universitas Tarumanagara) \\ (E-mail : melisaka96@gmail.com)
}

\author{
Stanislaus Atalim \\ (Corresponding Author)
}

(Dosen Hukum Perdata Fakultas Hukum Universitas Tarumanagara, Meraih Sarjana Hukum (S.H.) dari Universitas Indonesia, Magister Hukum (M.H.) dari Universitas Indonesia, Meraih Doktor Hukum (D.r.) dari Universitas Parahyangan.

(E-mail : $\underline{\text { st_atalim@yahoo.com) }}$

\begin{abstract}
This research was conducted to examine the rules concerning the protection of maternal right of women workers set forth in Labor Law. Basically, women workers have special right, their right must also be facilitated. One of the most fundamental right is the maternal right of women workers, including the right to menstruation leave, get social security in the form of care during childbirth and after childbirth, breast feeding and caring for the right and child rearing. This research also to look at the law as the principles of truth and justice that is natural and universally applicable. The method used in this research is normative research specifications. Juridical instruments used are equipped with the Labour Law Regulations related of legislation law, while the normative aspect associated with the materials related to the research literature. Implementation of maternity rights protection of women workers has been stated in the Labour Law and ILO Convention No. 183 Year 2000 on Maternity Protection (ILO Convention on Maternity Convention). The results of this research indicate that the implementation of maternity right not going well.
\end{abstract}

Keywords : Maternity Right, Protection of Woman Workers, Labor Law 


\section{PENDAHULUAN}

\section{A. Latar Belakang}

Perburuhan sekarang ini disebut dengan istilah ketenagakerjaan, sehingga hukum perburuhan sama dengan hukum ketenagakerjaan. Pengertian hukum perburuhan atau hukum ketenagakerjaan menurut ahli hukum yaitu Imam Soepomo, memberi pengertian bahwa hukum perburuhan adalah himpunan peraturan, baik tertulis maupun tidak tertulis, yang berkenaan dengan suatu kejadian pada saat seseorang bekerja pada orang lain secara formal dengan menerima upah tertentu. Dengan kata lain, hukum perburuhan adalah seperangkat aturan dan norma yang tertulis ataupun tidak tertulis yang mengatur pola hubungan industrial antara pengusaha dan pekerja atau buruh. ${ }^{1)}$

Istilah Hukum Perburuhan semakin tidak popular dengan diundangkannya Undang-Undang Nomor 13 Tahun 2003 tentang Ketenagakerjaan (UU Ketenagakerjaan) sebagai Undang-Undang payung bagi masalah-masalah yang terkait dengan hukum perburuhan atau hukum ketenagakerjaan. Menurut UU Ketenagakerjaan, pengertian ketenagakerjaan lebih luas dibandingkan dengan perburuhan sebagaimana dalam KUHPerdata. Sekalipun demikian, pelaksanaan peraturan perundangundangan dalam bidang ketenagakerjaan masih mempergunakan beberapa undang-undang yang dikeluarkan sebelum dikeluarkan UU Ketenagakerjaan. Dalam UU Ketenagakerjaan dirumuskan pengertian istilah ketenagakerjaan, yaitu segala hal yang berhubungan dengan tenaga kerja pada waktu sebelum, selama, dan sesudah masa kerja. Berdasarkan ketentuan Pasal 1 Angka 2 UU Ketenagakerjaan disebutkan bahwa Tenaga Kerja adalah setiap orang yang mampu melakukan pekerjaan guna

1) Iman Soepomo, Pengantar Hukum Perburuhan, Cetakan ke-12, (Jakarta: Djambatan, 1999), hal. 1. 
menghasilkan barang dan/atau jasa baik untuk memenuhi kebutuhan sendiri maupun untuk masyarakat. ${ }^{2)}$

Hukum perburuhan atau hukum ketenagakerjaan (Labour Law) merupakan bagian dari hukum yang berkenaan dengan pengaturan hubungan perburuhan, baik bersifat perseorangan maupun kolektif. ${ }^{3)}$ Tujuan pokok dari hukum ketenagakerjaan adalah melaksanakan keadilan sosial dalam perburuhan dengan melindungi buruh terhadap kekuasaan yang tidak terbatas dari pihak majikan agar bertindak sesuai dengan kemanusiaan. Sifat dari hukum perburuhan/ketenagakerjaan ini adalah mengatur yang ditandai dengan adanya aturan yang tidak sepenuhnya memaksa, bisa juga bersifat fakultatif (regelendrecht/aanvullendrecht) yang artinya hukum mengatur/melengkapi. Selain sifat mengatur terdapat juga sifat memaksa yang digunakan dalam pelaksanaan hubungan kerja untuk masalah tertentu yang membutuhkan campur tangan pemerintah sehingga menjadikan hukum ketenagakerjaan ini bersifat publik, sifat publik tersebut ditandai dengan ketentuan-ketentuan yang bersifat memaksa (dwingen), yang apabila tidak dipenuhi dapat diterapkan sanksi.

Pada hakekatnya pembangunan nasional merupakan pembangunan manusia Indonesia seutuhnya dan pembangunan masyarakat Indonesia seluruhnya. Pembangunan ini bergantung terhadap Tenaga Kerja karena Tenaga Kerja memegang peranan penting sebagai pelaku dan tujuan pembangunan tersebut. Perlu kiranya suatu sarana perlindungan pemeliharaan dan pengembangan terhadap kesejahteraan, terutama bagi mereka yang sedang mencari pekerjaan dan setelah berakhirnya hubungan kerja. Dengan adanya pembangunan nasional ini akan berpengaruh juga terhadap pembangunan dalam hal ketenagakerjaan. Pembangunan ketenagakerjaan ini harus diatur sedemikian rupa sehingga terpenuhi hak-

2) Indonesia, Undang-Undang Republik Indonesia Nomor 13 Tahun 2013 tentang Ketenagakerjaan (Lembar Negara Republik Indonesia Tahun 2003 Nomor 39, Tambahan Lembar Negara Republik Indonesia Nomor 4279), Pasal 1 angka 2.

3) Dedi Ismatullah, Hukum Ketenagakerjaan, Cetakan ke-1, (Bandung: Pustaka Setia, 2013), hal. 48. 
hak dan perlindungan yang mendasar bagi tenaga kerja dan pekerja/buruh serta pada saat bersamaan dapat mewujudkan kondisi yang kondusif bagi pengembangan dunia usaha. Pengertian perlindungan itu sendiri adalah sebagai tempat berlindung, perbuatan melindungi, pertolongan dan penjagaan. Seorang pekerja pasti memiliki hubungan kerja dengan setiap perusahaan yang mana dalam hubungan kerja tersebut perusahaan diwajibkan untuk memberikan perlindungan hukum terhadap tenaga kerjanya.

Perlindungan hukum adalah segala daya upaya yang dilakukan secara sadar oleh setiap orang maupun lembaga pemerintah, swasta yang bertujuan mengusahakan pengamanan, penguasaan dan pemenuhan kesejahteraan hidup sesuai dengan hak-hak asasi yang ada sebagaimana diatur dalam Undang-Undang Nomor 39 Tahun 1999 tentang Hak Asasi Manusia. Perlindungan hukum terhadap tenaga kerja menurut Imam Soepomo adalah penjagaan agar tenaga kerja dapat melakukan pekerjaan yang layak bagi kemanusiaan. Undang-Undang telah memberikan perlindungan terhadap hak-hak dasar pekerja. Pengusaha atau siapa pun yang melanggar hak-hak dasar pekerja dapat dijatuhkan sanksi mulai dari sanksi ringan seperti teguran, peringatan, pencabutan usaha sampai pada tingkat pelanggaran yang dapat digolongkan sebagai kejahatan sehingga dapat dikenakan sanksi kurungan dan pidana penjara ${ }^{4)}$. Hak-hak dasar pekerja tersebut antara lain menyangkut ${ }^{5)}$ :

1. Perlindungan upah

2. Jam kerja

3. Tunjangan Hari Raya

4. Jaminan Sosial Tenaga Kerja (JAMSOSTEK)

5. Kompensasi PHK

6. Hak Istirahat/Cuti

4) Editus Adisu dan Libertus Jehani, Hak-Hak Pekerja Peremuan, (Jakarta : Visi Media, 2007), hal. 5.

5) Ibid. hal 5. 
Salah satu hak dasar pekerja yang akan di bahas dalam penulisan ini adalah mengenai hak istirahat/cuti. Cuti adalah istirahat tahunan yang harus diambil oleh pekerja setelah bekerja selama 12 bulan berturut-turut. Kebijakan pemberian cuti kepada pekerja dituangkan dalam Pasal 79 UU Ketenagakerjaan yaitu pengusaha wajib memberi waktu istirahat dan cuti kepada pekerja/buruh. Cuti tahunan sekurang-kurangnya 12 hari kerja setelah pekerja buruh yang bersangkutan bekerja selama 12 bulan secara terus-menerus ${ }^{6}$. Mengenai mekanisme pengambilan cuti dapat diatur dalam perjanjian kerja bersama atau peraturan perusahaan yaitu apakah diambil sekaligus pada saat hari raya Idul Fitri atau hari raya Natal atau Imlek atau diambil sebagian pada hari raya Idul Fitri, hari raya Natal atau Imlek dan sebagiannya lagi pada saat ada keperluan. Hak cuti gugur bilamana dalam waktu 6 bulan setelah lahir nya hak, pekerja ternyata tidak mempergunakan haknya bukan karena alasan-alasan yang diberikan oleh majikan atau bukan karena alasan-alasan istimewa. Selama pekerja melaksanakan istirahat tahunan tersebut pekerja/buruh berhak atas upah penuh ${ }^{7)}$.

Gerakan emansipasi wanita di Tanah air telah berhasil dalam perjuangannya, sehingga kaum wanita dapat bekerja dilapangan apa saja, Banyak juga dijumpai di wilayah Prov. DKI Jakarta sebagai ibu kota di Indonesia banyak para wanita yang bekerja mencari nafkah, sehingga mereka mempunyai hak yang sama dengan kaum pria. Walaupun demikian para pengusaha yang mengerjakan tenaga-tenaga kerja wanita dalam bidang usaha/perusahaannya (sesuai dengan nilai-nilai Pancasila yang telah meresap dalam jiwanya), hendaknya dalam pemberian tugas atau penempatannya dalam jenis-jenis pekerjaan tertentu selalu memakai pertimbangan-pertimbangan yang sebijaksana mungkin, mengingat :

6) Indonesia, Undang-Undang Republik Indonesia Nomor 13 Tahun 2013 tentang Ketenagakerjaan. Op.Cit. Pasal 79.

${ }^{7)}$ Editus Adisu dan Libertus Jehani. Op.Cit. hal 22. 
1. para wanita umumnya bertenaga lemah, halus tetapi tekun;

2. norma-norma susila harus diutamakan, agar tenaga-tenaga kerja wanita tersebut tidak terpengaruh oleh perbuatan-perbuatan negatif dari tenaga-tenaga kerja lawan jenisnya, terutama kalau dikerjakan pada malam hari;

3. para tenaga kerja wanita itu umumnya mengerjakan pekerjaanpekerjaan halus yang sesuai dengan kehalusan sifat dan tenaganya;

4. para tenaga kerja wanita itu ada yang masih gadis dan ada pula yang telah bersuami atau berkeluarga yang dengan sendirinya mempunyai beban-beban rumah tangga yang harus dilaksanakannya pula. ${ }^{8)}$

Hal-hal tersebut diatas sangat diperhatikan oleh hukum dan perundangundangan di Indonesia, sehingga dalam mewujudkan perlindungan terhadap para tenaga kerja wanita, lahirlah ketentuan-ketentuan yang harus diperhatikan dan ditaati oleh tiap pengusaha yang akan mendayagunakan para tenaga kerja wanita dalam perusahaannya.

Namun sekarang ini banyak di jumpai, Perusahaan - perusahaan di Indonesia tepatnya di wilayah Prov. DKI Jakarta khususnya di Kawasan Industri Kawasan Berikat Nusantara (KBN) di Cakung, Jakarta Utara yang melanggar atau tidak menerapkan ketentuan undang-undang tersebut. Bentuk pelanggaran terhadap hak pekerja wanita tersebut antara lain yang pertama adalah terjadinya kekerasan seksual terhadap pekerja wanita seperti mengomentari bentuk tubuh atau cara berpakaian pekerja wanita, dipaksa kencan oleh atasan bahkan hingga diperkosa. Kemudian saat mengajukan cuti haid buruh perempuan yang bersangkutan diperiksa dengan cara menunjukkan darahnya. Kedua, kekerasan fisik seperti dipukul, dijewer, dicubit, dilempar benda keras dan digebrak meja. Ketiga, yaitu kekerasan verbal misalnya diancam atau diintimidasi dengan kata kasar, menakut-

\footnotetext{
${ }^{8)}$ Kartasapoetra, Hukum Perburuhan di Indonesia Berlandaskan Pancasila, (Jakarta: Bina Aksara, 1989), hal. 45.
} 
nakuti, menghina, dan memaki. Keempat, pelanggaran hak maternitas seperti keguguran ditempat kerja tidak dianggap kecelakaan kerja, tidak ada fasilitas bagi ibu hamil dan ruang laktasi. Lalu sulitnya mendapat cuti haid dan tidak ada tunjangan bagi buruh yang hamil dan melahirkan.

Pengertian hak maternitas itu sendiri sebenarnya belum diatur secara tepat namun pengertian itu dapat penulis artikan sebagai hak untuk mendapat pelayanan professional yang ditujukan kepada wanita usia subur yang berkaitan dengan masa diluar kehamilan, masa kehamilan, masa melahirkan, masa nifas sampai enam minggu, dan bayi yang dilahirkan sampai berusia 40 hari beserta keluarganya. Hak maternitas ini diatur dalam Konvensi ILO K-183 Konvensi Perlindungan Maternitas 2000. Dalam konvensi ini mengatur perlindungan kesehatan ibu dan anak yang diatur dalam Pasal 3 Konvensi ILO K-183, cuti melahirkan diatur dalam Pasal 4 Konvensi ILO K-183, cuti karena sakit atau komplikasi diatur dalam Pasal 5 Konvensi ILO K-183, perlindungan kerja dan non diskriminasi yang diatur dalam Pasal 8 dan Pasal 9 Konvensi ILO K-183, dan mengenai ibu menyusi yang diatur dalam Pasal 10 Konvensi ILO K-183 ${ }^{9)}$.

Perlindungan akan hak maternitas menjadi tanggung jawab semua pihak supaya wanita mempunyai hak untuk hidup bebas dari diskriminasi dan pelecehan, kemudian sebagai perlindungan bagi kaum perempuan saat sedang hamil, juga sebagai saran bagi perusahaan untuk tetap mempertahankan pekerja yang berkualitas, terampil dan berharga, dan juga menjamin agar perempuan terus dapat berkontribusi bagi pertumbuhan ekonomi negaranya. Sebagai salah satu contoh nyata kasus dilanggarnya pemenuhan terhadap hak-hak maternitas oleh pekerja wanita banyak terjadi di kalangan buruh di wilayah Kawasan Berikat Nusantara (KBN) Cakung. Hasil riset yang dilakukan oleh Komite Nasional Perempuan Mahardhika menyatakan banyak terjadi kekerasan berbasis gender di wilayah KBN Cakung ini. Alasan dipilihnya KBN Cakung ini sebagai wilayah penelitian

${ }^{9)}$ K-183 Konvensi Perlindungan Maternitas tahun 2000 
karena di KBN Cakung ini merupakan Kawasan yang mayoritas perusahaannya bergerak di bidang industri garmen, dimana mayoritas tenaga kerjanya adalah tenaga kerja wanita.

Berikut ini data Hasil Penelitian oleh Komite Nasional Perempuan Mahardika:

\begin{tabular}{|c|c|}
\hline Jumlah Pekerja & Hasil Penelitian \\
\hline 59 orang & $\begin{array}{l}\text { Pernah hamil dan takut mengalami } \\
\text { keguguran }\end{array}$ \\
\hline 177 orang & Takut kehilangan pekerjaan \\
\hline 7 orang & $\begin{array}{c}\text { Keguguran (3 orang tidak mendapat } \\
\text { cuti })\end{array}$ \\
\hline \multirow[t]{3}{*}{93 orang } & $\begin{array}{c}\text { Pernah hamil melahirkan antara } \\
\text { tahun } 2015-2017\end{array}$ \\
\hline & $\begin{array}{l}86 \text { orang melahirkan selamat (44 } \\
\text { orang diantaranta berstatus kontrak) }\end{array}$ \\
\hline & $\begin{array}{c}70 \text { orang mendapat cuti melahirkan } \\
\text { dari perusahaannya }\end{array}$ \\
\hline 74 orang & $\begin{array}{c}\text { Tidak mengetahui adanya izin } \\
\text { menyusui }\end{array}$ \\
\hline
\end{tabular}

Dalam kajian ini ditemukan tiga (3) fenomena yang secara langsung menyebabkan tingginya tekanan fisik dan psikis buruh hamil akibat adanya kewajiban lembur, keterbatasan fasilitas, dan sikap pengawas dalam memperlakukan buruh hamil. Lalu yang ke-dua adalah para buruh takut kehilangan pekerjaannya apabila mereka hamil kemudian melahirkan, 
karena pada kenyataannya sebagian besar buruh garmen di KBN Cakung berstatus buruh kontrak dan akan berdampak pada tingginya ketidakpastian (dan masa depan) kerja buruh. Ditemukan juga adanya fenomena menyembunyikan kehamilan pada sebagian buruh perempuan. Kemudian yang ketiga adalah rentan akan keguguran.

Tingginya beban kerja dan sikap pengawas yang kurang kooperatif ternyata meningkatkan kerawanan pada buruh hamil, sampai bisa menyebabkan keguguran. Dari hasil kajian ini pun ditemukan adaanya tujuh (7) buruh yang mengalami keguguran saat bekerja dan tiga (3) dari tujuh (7) buruh yang keguguran tidak mendapatkan cuti. Ke-tiga buruh tersebut berstatus buruh kontrak. Kemudian yang ke-empat didapati adanya 93 buruh perempuan yang pernah melahirkan antara tahun 2015-2017 ketika bekerja di wilayah KBN Cakung, dan perusahaan bersangkutan saat ini masih beroperasi. Dari 86 responden yang melahirkan selamat, sebagian besar (70 orang atau $79,6 \%$ ) mendapatkan cuti melahirkan dari perusahaan sesuai dengan ketentuan undang-undang. Sisanya sebanyak sejumlah 20,4\% (16 orang) tidak mendapatkan cuti melahirkan. Kemudian yang ke-lima terdapat kesulitan yang dilatarbelakangi oleh pentingnya ASI ekslusif bagi seorang bayi tentu tidak dapat disangkal lagi, bahkan pemerintah dengan berbagai peraturan menyatakan pentingnya menjamin kesempatan seorang bayi untuk mendapatkan ASI ekslusif, serta pentingnya melindungi ibu yang menyusui.

Kemudian ditemukan hasil penelitian antara lain para buruh hamil tidak mengetahui adanya ijin menyusui dan terbatasnya akses terhadap ruang laktasi. Banyak juga buruh yang sedang menyusui namun tidak menggunakan fasilitas ruang laktasi meskipun para buruh hamil mengetahui keberadaan fasilitas tersebut. Hal itu disebabkan karena bayi tidak boleh dibawa ke pabrik, kesulitan mengatur waktu untuk memerah ASI, Tidak diberi ijin oleh pengawas untuk meninggalkan pekerjaan. 
Berdasarkan hasil penelitian ini telah memberikan gambaran yang cukup jelas bagaimana kondisi buruh perempuan yang bekerja di KBN Cakung, sebagai sebuah Kawasan industri milik negara (BUMN). Pemenuhan hak maternitas pada buruh garmen perempuan yang bekerja di kompleks KBN Cakung ternyata belum sesuai dengan harapan. Hal ini terepresentasikan dalam beragamnya kendala atau problem maternitas yang dihadapi para buruh perempuan, serta keberadaan buruh perempuan yang tidak mendapatkan hak-hak maternitasnya, sesuai ketentuan dalam UU Ketenagakerjaan. Sayangnya sampai saat ini Pemerintah Indonesia tidak mampu menindak tegas perusahaan yang melanggar pelanggaran terhadap hak maternitas dari para pekerja wanita tersebut. Banyak juga para pekerja wanita yang telah mengadukan nya kepada Dinas Ketenagakerjaan, Namun bukan nya mendapat respon yang baik tetapi malah mendapat respon yang minim. Dinas ketenagakerjaan enggan melakukan pemeriksaan terhadap perusahaan yang dilaporkan dengan alasan minim nya Sumber Daya Manusia (SDM) yang ada.

Berdasarkan uraian latar belakang masalah tersebut di atas, Dinyatakan judul penulisan ini adalah "Implementasi Perlindungan Hukum terhadap Hak Maternitas Pekerja Wanita di Kawasan Berikat Nusantara (KBN) Cakung Jakarta Utara ditinjau dari Undang-Undang Ketenagakerjaan”

\section{B. Perumusan Masalah}

Berdasarkan pemaparan dalam latar belakang yang telah diuraikan sebelumnya, permasalahan yang hendak diteliti dalam penulisan ini yaitu "Bagaimana Implementasi Perlidungan Hukum terhadap Hak Maternitas Pekerja Wanita di Kawasan Berikat Nusantara (KBN) Cakung, Jakarta Utara ditinjau dari Undang-Undang Ketenagakerjaan?"

\section{PEMBAHASAN}




\section{A. Pengimplementasi Perlindungan Hukum terhadap Hak Maternitas}

\section{Pekerja Wanita ditinjau dari Undang-Undang Ketenagakerjaan}

Menurut penulis, Pengertian perlindungan hukum diambil dari kata perlindungan terlebih dahulu, Perlindungan berarti mengayomi sesuatu dari hal-hal yang berbahaya, sesuatu itu bisa saja berupa kepentingan maupun benda atau barang. Selain itu perlindungan juga mengandung makna pengayoman yang diberikan terhadap orang yang lebih lemah. Dengan demikian, perlindungan hukum dapat diartikan sebagai sebagai segala upaya pemerintah untuk menjamin adanya kepastian hukum untuk memberi perlindungan kepada warga negaranya agar hak-hak nya sebagai warganegara tidak dilanggar, dan bagi yang melanggar akan dikenakan sanksi sesuai dengan peraturan yang berlaku. Perlindungan yang diberikan oleh pemerintah dapat bersifat preventif maupun represif. Perlindungan yang akan penulis bahas dalam uraian permasalah ini adalah mengenai perlindungan terhadap hak maternitas pada pekerja wanita.

Pada umumnya sebelum seseorang dapat dikatakan sebagai pekerja, antara pekerja dengan pemberi kerja melakukan yang namanya hubungan kerja yang sekarang ini disebut dengan perjajian kerja. Dalam perjanjian kerja timbul kewajiban suatu pihak untuk bekerja. Hubungan kerja dilakukan minimal oleh 2 (dua) subjek hukum mengenai suatu pekerjaan. Timbulnya perjanjian kerja berarti telah menandakan bahwa adanya kesepakatan kerja yang terjadi di antara ke-dua belah pihak. Tentunya isi dari sebuah perjanjian kerja tersebut dibuat sesuai dengan ketentuan UU Ketenagakerjaan yang berlaku saat ini. Agar tidak terjadi kesewenangwenangan dari pemberi kerja/pengusaha karena hakikat hukum UU Ketenagakerjaan adalah melindungi pekerja dari tindakan kesewenangwenangan suatu pengusaha. Pekerja adalah Wanita adalah manusia yang dimana manusia itu mempunyai hak dan kewajiban dalam kehidupannya. Pekerja Wanita berarti merupakan manusia yang mempunyai hak yang seharusnya ia peroleh dan kewajiban yang seharusnya ia laksanakan. Wanita dalam kodrat nya mempunyai posisi kusus dalam pandangan 
masyarakat. Hal itu semua disebabkan karena wanita dalam kodrat nya mempunyai kondisi fisik yang berbeda dengan laki-laki. Wanita dalam kehidupannya reproduksinya mengalami yang dinamakan dengan menstrusi, mengandung, melahirkan, dan menyusui bayi yang telah dilahirkannya. Karena kekhususan yang melekat dalam diri wanita ini mengakibatkan timbulnya pengaturan khusus dalam Undang-Undang yang mengatur tentang hak dan kewajiban wanita.

Dalam konteks hukum ketenagakerjaan, Pekerja wanita ini memiliki hak khusus yang mengatur tentang wanita. Hak tersebut disebut dengan Hak Maternitas pekerja wanita. Pengertian hak maternitas itu sendiri adalah hak untuk mendapatkan pelayanan professional yang ditujukan kepada wanita usia subur yang berkaitan dengan masa diluar kehamilan, masa kehamilan, masa melahirkan, masa nifas sampai enam minggu, dan bayi yang dilahirkan sampai berusia 40 hari beserta keluarganya. Pengaturan terhadap hak maternitas ini dapat kita temukan didalam Konvensi ILO nomor K-183 Perlindungan Maternitas tahun 2000. Hak maternitas ini berfokus pada pemenuhan kebutuhan dasar dalam melakukan adaptasi fisik dan psikososial proses keperawatan maternitas. Pengaturan terhadap hak maternitas selain yang terdapat didalam Konvensi ILO nomor K-183 Perlindungan Maternitas tahun 2000 diatur juga didalam UU Ketenagakerjaan dan Peraturan Menteri Tenaga Kerja. Didalam UU Ketenagakerjaan dapat kita lihat pengaturan hak maternitas tercantum dalam Pasal 76 UU Ketenagakerjaan ${ }^{10)}$ :

1. pekerja/buruh perempuan yang berumur kurang dari 18 (delapan belas) tahun dilarang dipekerjakan antara pukul 23.00 s.d. 07.00 .

2. pengusaha dilarang mempekerjakan pekerja/buruh perempuan hamil yang menurut keterangan dokter berbahaya bagi kesehatan dan keselamatan kandungannya maupun dirinya apabila bekerja antara pukul 23.00 s.d. pukul 07.00 .

\footnotetext{
${ }^{10)}$ Indonesia, Undang-Undang Republik Indonesia Nomor 13 Tahun 2013 tentang Ketenagakerjaan. Op.Cit. Pasal 76.
} 
3. pengusaha yang mempekerjakan pekerja/buruh perempuan antara pukul 23.00 s.d. pukul 07.00 wajib :

1) memberikan makanan dan minuman bergizi; dan

2) menjaga kesusilaan dan keamanan selama di tempat kerja.

4. Pengusaha wajib meyediakan angkutan antar jemput bagi pekerja/buruh perempuan yang berangkat dan pulang bekerja antara pukul 23.00 s.d. pukul 05.00.

Selain pengaturan terkait hak maternitas yang diatur di dalam UU Ketenagakerjaan diatur juga perlindungan terhadap tenaga kerja wanita yang bekerja pada malam hari tepatnya pengaturan mekanisme jam operasional pekerja wanita untuk bekerja di dalam Keputusan Menteri Tenaga Kerja yang menyangkut perlindungan terhadap keamanan pemerintah mengatur apabila perempuan bekerja pada malam hari yaitu antara pukul 23.00 s/d 07.00. Keputusan Menteri Tenaga Kerja dan Transmigrasi RI No. Kep 224/Men/2003 mengatur kewajiban pengusaha yang mempekerjakan pekerja/buruh perempuan antara pukul $23.00 \mathrm{~s} / \mathrm{d}$ 07.00. Inti dari Kepmen tersebut adalah menyangkut perlindungan keamanan fisik dan psikis pekerja perempuan yang bekerja pada malam hari agar terhindar dari perampokan, pemerasan, maupun tindakan asusila berupa pemerkosaan dan pelecehan seksual. Tanggung jawab yang berkaitan dengan perlindungan ini dibebankan kepada pengusaha. Konkritnya pengusaha diwajibkan :

1. Menyediakan angkutan antar jemput untuk pekerja perempuan yang bekerja dan pulang pukul $23.00 \mathrm{~s} / \mathrm{d} 05.00$.

2. Pengusaha juga diwajibkan menyediakan petugas keamanan ditempat kerja untuk memastikan bahwa pekerja perempuan aman dari kemungkinan perbuatan asusila ditempat kerja.

3. Fasilitas tempat kerja harus didukung oleh kamar mandi/WC dan penerangan yang layak. 
4. Untuk menjaga kondisi kesehatan agar pekerja perempuan harus dalam kondisi prima, pengusaha diwajibkan memberikan makanan dan minuman yang bergizi sekurang-kurangnya 1.400 kalori.

Pasal 81 ayat 1 UU Ketenagakerjaan ${ }^{11)}$ tentang cuti haid, Cuti haid bagi perempuan adalah sesuatu yang tetap menjadi pro dan kontra. Ketentuan mengenai cuti haid diatur dalam pasal 81 ayat 1 UndangUndang Nomor 13 Tahun 2003 mengatur tentang cuti haid bagi perempuan.

Pasal 82 UU Ketenagakerjaan ${ }^{12)}$ yang mengatur tentang cuti hamil selama tiga bulan yang boleh dibagi menjadi dua bagian seperti 1,5 bulan sebelum saatnya melahirkan dan 1.5 bulan setelah melahirkan. Kemudian diatur juga cuti keguguran yang diberikan selama 1,5 bulan, selain itu juga terdapat dalam Pasal 83.

Kebijakan pemerintah untuk memberikan cuti hamil kepada perempuan adalah sesuatu yang wajib karena keterkaitan kodrat sebagai perempuan. Diatur dalam pasal 82 Undang-Undang Nomor 13 Tahun 2003 tentang Ketenagakerjaan, dikatakan bahwa pekerja/buruh perempuan berhak memperoleh istirahat 1,5 (satu setengah) bulan sebelum saatnya melahirkan anak dan 1,5 bulan sesudah melahirkan menurut perhitungan dokter kandungan atau bidan. Untuk pekerja/buruh perempuan yang mengalami keguguran kandungan berhak memperoleh istirahat 1,5 bulan atau sesuai dengan surat keterangan dokter atau bidan. Mekanisme pengambilan cuti hamil bisa disepakati antara pekerja/buruh dengan pengusaha dan dituangkan dalam perjanjian kerja bersama atau peraturan perusahaan. Mekanisme pengambilan cuti hamil yang dimaksud tidak mesti 1,5 bulan sebelum melahirkan dan 1,5 bulan setelah melahirkan bisa

\footnotetext{
11) Indonesia, Undang-Undang Republik Indonesia Nomor 13 Tahun 2013 tentang Ketenagakerjaan. Op.Cit. Pasal 81.

12) Indonesia, Undang-Undang Republik Indonesia Nomor 13 Tahun 2013 tentang Ketenagakerjaan. Op.Cit. Pasal 82.
} 
diatur apakah 1 minggu atau 2 minggu sebelum melahirkan baru sisanya diambil setelah melahirkan. Yang penting total istirahat selama periode melahirkan adalah 3 bulan. Apabila cuti tahunan jatuh temponya tepat pada saat mengambil cuti hamil maka cuti tahunannya tetap berlaku.

Jika dilihat dalam hal pengaturan mengenai regulasinya sebernarnya pengaturan mengenai hak maternitas pekerja wanita ini dirasa sudah cukup baik. Pemerintah telah menyiapkan pengaturan tersebut guna untuk melindungi pekerja wanita agar dapat melakukan pekerjaan yang layak bagi kemanusiaan. Teori perlindungan menurut Soepomo mencakup semua kebutuhan bagi pekerja wanita yaitu antara lain teori perlindungan ekonomis dimana pengertiannya adalah perlindungan tenaga kerja dalam bentuk penghasilan yang cukup, termasuk bila tenaga kerja tidak mampu bekerja diluar kehendaknya. Teori ekonomis ini jika dikaitkan dengan pekerja wanita, yang dimaksud dengan "bila tenaga kerja tidak mampu bekerja diluar kehendaknya" hal-hal yang diluar kehendak wanita seperti dia mengalami haid, hamil atau keguguran dan bahkan kewajibannya untuk menyusui masuk dalam kategori tersebut. Kemudian teori yang kedua yaitu teori perlindungan sosial yang isi nya perlindungan terhadap tenaga kerja dalam bentuk jaminan kesehatan kerja, dan kebebasan berserikat dan perlindungan hak untuk berorganisasi dapat dilihat kaitannya dengan hak maternitas adalah haid, kehamilan, melahirkan, keguguran dan menyusui juga merupakan bagian dari jaminan kesehatan kerja para pekerja wanita. Lalu pada teori yang terakhir yaitu teori perlindungan teknis berkaitan dengan hak maternitas dapat kita lihat dalam hal pekerja wanita boleh izin untuk tidak bekerja apabila mereka merasakan sakit pada saat menstruasi datang, cuti pada saat mereka sedang hamil maupun keguguran, kebijakan ketentuan lembur apabila mereka sedang hamil dimana banyak terjadi penyimpangan bahwa pekerja wanita yang sedang hamil tetap diberlakukan jam kerja lembur yang membahayakan kesehatan janin dan dirinya. Dan juga perlindungan dalam 
bentuk penyediaan angkutan penjemputan apabila mereka bekerja pada malam hari serta dilindungi dari perlakuan yang tidak semestinya dari rekan kerja mereka yang lawan jenis.

Dari kasus pelanggaran terhadap hak maternitas pekerja wanita yang terjadi di wilayah KBN Cakung ini sebenarnya dapat dilihat bahwa kurangnya kepedulian pihak perusahaan terhadap pekerja wanita baik dari segi kesehatan maupun keamanan kerja mereka. Karena kasus pelanggaran yang terjadi berupa tetap diberlakukannya jam kerja lembur bagi mereka para pekerja wanita yang sedang hamil, bahkan ada yang sedang hamil besar. Dalam kaitannya dengan kesehatan tentu hal ini berbahaya bagi kesehatan janin maupun kesehatan ibunya, wanita yang sedang hamil semestinya melakukan banyak istirahat, namun karena tuntutan ekonomi maka mereka tetap harus bekerja agar tetap mendapatkan penghasilan untuk mencukupi kebutuhan hidup mereka. Selain itu data dilihat juga adanya kasus dimana pekerja wanita sedang hamil ingin mempergunakan hak cuti hamil mereka selama 3 (tiga bulan), namun pada kenyataan nya pada saat hak cuti itu di ambil dan setelah selesai menjalani masa cuti tersebut hubungan kerja pekerja wanita telah diputus sepihak oleh pihak perusahaan tanpa adanya pemberitahuan yang lebih lanjut dari pihak perusahaan, kemudian telah digantikan dengan posisi pekerja yang baru. Kemudian terkait dengan cuti keguguran yang harusnya diterima selama 1,5 bulan oleh pekerja wanita, hanya diperoleh dalam kurun waktu kurang dari 1,5 bulan yaitu beberapa hari saja, bahkan ada yang tidak memperolehnya sama sekali.

Tentu hal ini telah sangat meyalahi atau tidak sesuai dengan aturan perundang-undangan, menurut penulis perusahaan telah melanggar ketentuan Pasal 81 UU Ketenagakerjaan dan Pasal 82 UU Ketenagakerjaan yang mengatur tentang cuti melahirkan dan cuti keguguran. yang seharusnya perusahaan mendapatkan sanksi dari pelanggaran terhadap UU ketenagakerjaan, seperti sanksi berupa peringatan dari Pemerintah terkait Ketenagakerjaan ataupun pemberian 
sanksi dengan pencabutan izin usahanya ataupun sanksi dalam bentuk lain. Dalam hal pengaturan regulasi nya sendiri dirasa sudah cukup bagus seperti penuturan Bapak Sehat Damanik yang melihat hukum ketenagakerjaan dari sisi seorang praktisi. Namun yang kurang baik adalah pelaksanaan dari regulasi tersebut. Perlu ditingkatkan lebih lagi pengawasan yang lebih ketat dari pihak Pemerintah. Kemudian jika dilihat dari sisi Kementrian Ketenagakerjaan sendiri beranggapan bahwa mereka telah melakukan pengawasan yang menyeluruh terhadap hubungan perusahaan-perusahaan dengan pekerjanya khususnya pekerja wanita. Dan menurut penuturan salah satu Direktur divisi Ketenagakerjaan Wanita di Kementrian Ketenagakerjaan mengatakan bahwa mereka belum menerima aduan secara langsung terkait pelanggaran hak maternitas yang terjadi di Kawasan Berikat Nusantara (KBN) Cakung, menurutnya pengaduan tersebut adalah bagian dari Dinas Ketenagakerjaan Prov. DKI Jakarta. Namun apabila dilihat dari sisi sebuah organisasi yang bernama Komite Perempuan Mahardhika yang langsung terjun ke lapangan, membaur atau bersosialisasi secara langsung dengan para korban pelanggaran hak maternitas, perlindungan dari Pemerintah terhadap pekerja wanita sangat minim adanya. Komite Perempuan Mahardhika banyak membantu para korban untuk mendapatkan keadilan yang seharusnya diperoleh oleh mereka, namun yang mereka dapatkan hanyalah ketidakpastian dari Pemerintah. Yang menurutnya Pemerintah lebih berpihak kepada Perusahaan dibanding kepada pekerja wanita yang terabaikan haknya.

Menurut penulis kasus pelanggaran terhadap hak maternitas ini perlu mendapatkan perhatian yang lebih serius lagi baik dari Pemerintah maupun dari pihak-pihak perusahaan. Pada hakikat nya hukum itu berguna untuk melindungi kepentingan seseorang. Hukum dalam hal ini adalah peraturan-peraturan terkait dengan ketenagakerjaan. Karena dalam hal ini apabila Pemerintah dapat mengatasi bahkan memberantas kasus ini maka akan timbul keadilan di mata para pekerja wanita yang dimana mereka dapat memperoleh hak yang seharusnya mereka peroleh. Sehingga akan 
mengurangi kasus-kasus pelanggaran terhadap hak-hak pekerja wanita dalam dunia ketenagakerjaan Indonesia. Seharusnya rasa kemanusiaan dalam hal ini perlu untuk ditingkatkan lebih lagi karena mengingat pekerja wanita adalah khusus dalam posisinya dan melihat dampak kedepan dari adanya pelanggaran terhadap hak maternitas di Indonesia, seperti apabila pekerja wanita tetap diwajibkan untuk lembur yang akan membahayakan dirinya serta janin yang dikandungnya apabila dilihat pada kondisi terburuknya salah satu dari mereka akan mengalami kematian atau bahkan ke-dua dari mereka sekaligus yang dapat berimbas pada meningkatnya angka kematian perempuan dan bayi di Indonesia. Sedangkan Indonesia sendiri memiliki banyak program yang salah satunya adalah program untuk menurunkan angka kematian pada ibu hamil dan juga angka kematian yang terjadi pada janin/bayi. Apabila pengawasan ini berjalan dengan baik, tidak hanya baik bagi dunia ketenagakerjaan saja namun juga baik untuk membantu menjalankan program yang telah dibuat oleh Pemerintah. Dan jika dilihat dari segi keamanan, keamanan kerja dari para pekerja wanita juga perlu lebih lagi untuk ditingkatkan keamanan yang benar-benar dapat memberikan rasa aman bagi para pekerja wanita. Agar mereka juga mendapatkan hak nya untuk mendapatkan rasa aman serta mengurangi semakin banyak timbulnya pelecehan yang terjadi terhadap wanita, baik secara mental maupun fisik. Sehingga dapat membantu meminimalisir angka kejahatan ataupun kriminalitas di negara ini. Kemudian jika dilihat dari segi perekonomian, banyak pekerja wanita yang takut untuk mengadukan pelanggaran yang terjadi baik yang menimpa dirinya maupun rekan kerja nya dengan alasan bahwa mereka takut apabila mereka mengadukan atau melaporkan adanya pelanggaran hak maternitas terhadap para pekerja perempuan maka mereka akan kehilangan pekerjaan mereka. Karena apabila aduan ataupun laporan itu sampai kepada pemerintah atau pihak-pihak yang berkewenangan untuk menanganinya maka bisa dipastikan bahwa perusahaan yang bersangkutan akan mengalami kerugian, kerugian tersebut bisa dalam berbagai macam bentuk 
yang akibat dari adanya kerugian yang dialami oleh perusahaan yang diadukan atau dilaporkan ini akan berimbas pada diberhentikannya pihak yang telah membuat si perusahaan ini merasa rugi. Jadi apabila proses pengaduan berjalan dengan baik dan benar sesuai dengan prosedur, kemudian para pekerja wanita yang sebelumnya dirugikan kemudian dapat memperoleh haknya belum tentu posisi pekerjaan yang mereka duduki sekarang tetap dapat mereka jalankan. Dengan ada nya hal ini seharusnya tanpa ada nya aduan terlebih dahulu, Pemerintah sudah dapat bergerak sendiri untuk menelusuri lebih jauh mengenai pemenuhan hak oleh setiap perusahaan terhadap para pekerja nya, khususnya pekerja wanita. Karena pekerja wanita berada dalam posisi yang lebih rendah dan lemah, mereka tidak akan sanggup untuk berjalan sendiri mencari keadilan terhadap hak mereka tanpa adanya bantuan serta dukungan yang baik dari pihak pemerintah, dimana pemerintah memiliki posisi yang paling tingi di negara ini. Tentunya dengan posisi kekuasaan yang dimilikinya memang diperuntukan membantu kaum yang lemah yang posisi mereka berada dibawahnya untuk memperoleh maupun untuk melindungi kepentingan yang memang sudah seharusnya menjadi milik mereka.

\section{PENUTUP}

\section{A. Kesimpulan}

Dari hasil penelitian terhadap implementasi perlindungan hukum terhadap hak maternitas pekerja wanita di KBN Cakung, Penulis dalam hal ini menarik kesimpulan yang akan dipaparkan sebagai berikut ini :

Dalam praktiknya masih banyak dijumpai kasus pelanggaran terhadap hak maternitas pekerja perempuan namun tidak semua kasus tersebut dapat sampai pada pihak yang berwajib atau yang memiliki wewenang untuk menyelesaikannya. Tidak banyak para pekerja wanita yang berani mengadukan pelanggaran hak yang menimpa pada dirinya karena banyak faktor-faktor akibat yang menjadi pertimbangan mereka apabila mereka melaporkan kasus pelanggaran hak yang menimpa dirinya. 
Di satu sisi mereka membutuhkan pekerjaan untuk memenuhi kehidupannya, apabila mereka membawa kasus pelanggaran hak tersebut kepada pihak yang berhak untuk menanganinya maka sumber mata pencahariannya akan terancam nasibnya. Hal ini disebabkan oleh faktor ekonomi yang menghambat mereka untuk dapat berlaku tegas sesuai dengan peraturan hukum yang berlaku, selain itu karena mereka para pekerja perempuan tergolong dalam posisi yang lebih rendah dan lemah. Pengaturan regulasi terkait hak maternitas sebenarnya telah disusun secara baik oleh pemerintah, dalam penyusunannya telah di sesuaikan dengan kondisi pekerja wanita di Indonesia, khususnya di wilayah Prov. DKI Jakarta. Namun hanya saja pelaksanaan dari Peraturan Menteri Ketenagakerjaan, Undang-Undang Ketenagakerjaan maupun Konvensi ILO yang terkait dengan hak maternitas dirasakan masih sangat kurang. Dalam artian keberlakuan dari peraturan-peraturan tersebut masih belum berjalan dengan baik.

Pemerintah masih kurang tegas dalam menindaklanjuti kasus-kasus pelanggaran hak yang terjadi di perusahaan-perusahaan, Bahkan tidak sedikit dari pihak Pemerintah yang dalam melaksanakan penegasan terhadap pelanggaran ini menjadi lebih condong atau berpihak kepada perusahaan yang jelas-jelas bersalah melakukan pelanggaran. Hal ini terjadi karena adanya praktik kongkalikong antara perusahaan pelanggar hak pekerja wanita tersebut dengan pemerintah karena adanya suatu kekuasaan dari pihak perusahaan. Seharusnya pihak pemerintah dapat berlaku bersih dalam menjalankan tugasnya agar mudah untuk melaksanakan regulasi dari ketentuan undang-undang nya, sehingga dapat meminimalisir terjadinya praktik kongkalikong antara pemerintah dengan perusahaan-perusahaan. Hal ini dirasakan juga menjadi faktor penghambat yang cukup berpengaruh dalam proses pelaksaan regulasi nya. Karena dalam proses menegakkan suatu aturan tidak hanya dilakukan dari satu pihak saja, namun dari kedua belah pihak agar terciptanya sebuah keserasian dalam penegakkan aturan. 
Kasus pelanggaran hak maternitas pada pekerja wanita di KBN Cakung ini merupakan salah satu contoh yang dapat dijadikan bukti bahwa pengawasan yang dilakukan serta regulasi ataupun peraturan perundangundangan yang dijalankan oleh pemerintah pada saat ini belum berjalan dengan baik. Apabila suatu pengawasan yang dilakukan oleh pemerintah berjalan dengan baik dan dilakukan secara ketat mungkin hal yang terjadi dalam kasus ini tidak terjadi. Dan pemenuhan terhadap hak-hak tiap pekerja wanita dapat terpenuhi dengan baik sesuai hak nya masing-masing. Apabila hak-hak pekerja wanita khusus nya hak maternitas mereka terpenuhi maka akan sangat banyak memberikan dampak positif bagi tiap sektor di negara ini, terutama dalam sektor ekonomi. Para pekerja wanita dapat bekerja dengan baik dan sejahtera tanpa adanya ketakutan untuk mengakui bahwa dirinya sedang hamil, ataupun para pekerja wanita yang hamil tidak akan khawatir nasib kesehatan janin yang dikandungnya ketika ia sedang bekerja, begitu juga dengan keselamatan dan keamanan terhadap dirinya sendiri pada saat sedang melakukan pekerjaan.

\section{B. Saran}

Menurut Penulis, Kementrian ketenagakerjaan sebagai pihak yang berwenang mengatasi berbagai permasalahan yang terjadi kepada tenaga kerja seharusnya mengetahui lebih lanjut mengenai kasus pelanggaran terhadap hak pekerja wanita yang terjadi di wilayah KBN Cakung ini, walaupun aduan akan kasus itu tidak disampaikan melalui Kementrian Ketenagakerjaan tetapi melalu Dinas Ketenagakerjaan, karena Dinas Ketenagakerjaan juga merupakan bagian dari Kementrian Ketenagakerjaan sebagai lembaga yang tertinggi dalam hal ketenagakerjaan. Diharapkan Kementrian Ketengakerjaan lebih ketat lagi dalam melaksanakan pengawasan nya kepada perusahaan-perusahaan karena kasus pelanggaran hak ini sebenarnya banyak terjadi di Indonesia namun jarang sekali atau bahkan penangannya tidak sampai di jalur hukum, hal ini di akibatkan oleh minimnya aduan dari para pekerja wanita yang disampaikan kepada pihak 
pemerintah. Hal ini dilator belakangi oleh rasa takut yang dirasakan oleh para pekerja wanita, apabila upaya mereka dalam memperoleh hak nya berhasil, keberlangsungan dari pekerjaan mereka akan berjalan terus. Mereka takut akan kehilangan pekerjaan mereka karena sebagian dari mereka pun juga berperan sebagai tulang punggung keluarga.

Penulis berharap untuk kedepannya pelaksanaan terhadap pengimplementasian dari ketentuan mengenai pemberian hak maternitas kepada para pekerja wanita yang sudah ada dapat diterapkan dan dijalankan dengan lebih baik lagi, Selain memperhatikan jalannya pengaturan terhadap peng-implemntasian hak maternitas ini juga penting untuk diperhatikan lebih lagi mengenai penindakan dari Pemerintah untuk dapat lebih di perketat lagi terhadap pengawasan mengenai berjalan atau tidak nya peng-implementasian hak maternitas ini pada perusahaan-perusahaan yang mempekerjakan pekerja wanita. Selain itu juga yang perlu menjadi perhatian serius adalah pengawasan terhadap staff baik dari pihak kementrian ketenagakerjaan maupun dinas ketenagakerjaan yang terjun langsung kelapangan untuk melakukan pengecekan, agar dipastikan bahwa mereka bekerja dengan baik dan benar sesuai dengan prosedur yang ada serta bebas dari aksi suap maupun praktik kongkalikong yang dilakukan oleh pihak perusahaan dengan staff baik dari kementrian ketenagakerjaan maupun dinas ketenagakerjaan yang tugas nya melakukan pengecekan keberlakuan suatu regulasi UU Ketenagakerjaan di perusahaan-perusahaan yang ada. Karena menurut penulis sekarang ini dirasakan masih sangat kurang baik pelaksanaan dari perarutan perundang-undangan yang ada. Sehingga harus dapat dipastikan lebih lagi bahwa dari pihak pemerintah telah menjalankan peraturan dari perundangan-undangan dengan baik, benar dan bersih sesuai dengan sebagaimana mestinya. Hal ini dimaksudkan agar Pemerintah lebih mudah untuk mentertibkan jalannya peraturan di dalam dunia ketenagakerjaan. Agar tercipta kesejahteraan bagi dunia ketenagakerjaan di Indonesia. 
Selain itu pemerintah dapat mewujudkan hakikat hukum yaitu untuk melindungi kepentingan seseorang. Selain itu pemerintah juga berperan dalam memberikan perlindungan hukum bagi para pekerja wanita. Penulis mengartikan perlindungan hukum itu sebagai perlindungan terhadap seseorang untuk mereka memperoleh hak dan kewajibannya agar mereka memperoleh rasa aman. Besar harapan penulis untuk pemerintah agar selalu bekerja lebih baik lagi setiap harinya dalam melaksanakan peraturan-peraturan yang telah dibuatnya. Untuk para wanita yang bekerja atau penulis sebut para pekerja wanita untuk lebih berani menyuarakan apa yang menjadi keluhan nya atau mengadukan atau melaporkan kejadian yang merugikan yang menimpa dirinya kepada para instansi pemerintah yang berwenang. Khusus nya apabila mereka mengalami kerugian terhadap hak maternitas yang seharusnya mereka peroleh, mengenai ketakutan akan kehilangan pekerjaan setelah bertindak tegas untuk mendapatkan hak nya, tentunya ini sudah menjadi bagian dari tanggung jawab pemerintah dalam sektor ekonomi untuk menyediakan banyak lapangan pekerjaan bagi para pekerja wanita apabila setelah mengadukan atau melaporkan kerugian hak maternitas yang mereka alami mereka dipecat atau diberhentikan dari pekerjaannya, seharusnya pemerintah sudah menyiapkan lapangan usaha pengganti sebagai bentuk apresiasi kepada pekerja wanita yang berani untuk menyuarakan suara nya. Karena tidak mudah tentunya untuk melakukan hal tersebut, terlepas dari hal itu para pekerja wanita memiliki latar belakang yang berbeda-beda namun sebagaian besar dari mereka merupakan tulang punggung keluarga mereka. Jadi apabila mereka berani untuk berikap tegas tentunya mereka juga telah berani berkorban mempertaruhkan mata pencahariannya demi keadilan yang mereka ingin peroleh. Jadi sudah sepantasnya pemerintah bisa memberikan penghargaan yang berarti dari sebuah pengorbanan yang telah di lakukan oleh para pekerja wanita.

\section{DAFTAR PUSTAKA}

\section{A. Buku-Buku}



2.

Adisu, Editus dan Libertus Jehani. Hak-Hak Pekerja Perempuan.Cetakan ke-

(Jakarta: Visi Media, 2007).

Ali, Zainuddin. Metode Penelitan Hukum. (Jakarta: Sinar Grafika, 2010).

Asyhadie, Zaeni. Hukum Kerja. (Jakarta: Rajawali Press, 2007).

Husni, Lalu. Hukum Ketenagakerjaan Indonesia. Cetakan ke-4. (Jakarta: Raja Grafindo Persada, 2003).

Ismatullah, Dedi. Hukum Ketenagakerjaan Indonesia. Cetakan ke-1. (Bandung: Pustaka Setia, 2013).

Kansil, CST. Pengantar Ilmu Hukum dan Tata Hukum Indonesia. (Jakarta: Balai Pustaka, 1989).

Kartasapoetra. Hukum Perburuhan di Indonesia Berlandaskan Pancasila. (Jakarta: Bina Aksara,1989).

Marzuki, Peter Mahmud. Penelitian Hukum. (Jakarta: Kencana, 2013).

Marzuki, Peter Mahmud. Pengantar Ilmu Hukum. (Jakarta: Kencana, 2014).

Mertokusumo, Sudikno. Penemuan Hukum. (Bandung: Citra Aditya Bakti, 2009).

Soeroso, R. Pengantar Ilmu Hukum. (Jakarta: Sinar Grafika, 2006).

Rahardjo, Satjipto. Ilmu Hukum. (Bandung: PT. Citra Aditya Bakti, 2014).

Soekanto, Soerjono dan Sri Mamudji. Penelitian Hukum Normatif Suatu Tinjauan Singkat. (Jakarta: PT Raja Grafindo Persada, 2009).

Soepomo, Iman. Pengantar Hukum Perburuhan. (Jakarta: Djambatan, 2003).

Uwiyono, Aloysius et al. Asas-Asas Hukum Perburuhan. (Depok: Raja Grafindo Persada, 2014)

Wijayanti, Asri. Hukum Ketenagakerjaan Pasca Reformasi. (Jakarta: Sinar Grafika, 2010).

\section{B. Peraturan Perundang-Undangan}


Indonesia. Undang-Undang Dasar Negara Republik Indonesia Tahun 1945. (Jakarta: Tatanusa, 2000).

Undang-Undang Republik Indonesia Nomor 13 Tahun 2003 tentang Ketenagakerjaan (Lembar Negara Republik Indonesia Tahun 2003 Nomor 39, Tambahan Lembar Negara Republik Indonesia Nomor 4279).

. Peraturan Menteri Tenaga Kerja No. Permen 03/Men/198.

Indonesia. Keputusan Menteri Tenaga Kerja dan Transmigrasi RI No. Kep.224/Men/2003.

\section{Artikel atau Makalah Internet}

Anonim. http://kabarburuh.com/2017/03/03/nasib-pekerja-perempuanindonesia-tak-semanis-gula-gula-regulasil, 3 Maret 2017.

.https://www.koranperdjoeangan.com/perlindungan-bagipekerjaburuh-perempuan-yang-hamil/, 19 Maret 2017.

.https://www.cnnindonesia.com/gaya-hidup/20151219032825-27799253/kisah-buruh-perempuan-di-tempat-kerja. 19 Desember 2017. 